\title{
Exploring linkages among external integration, supply chain risk reduction and performance outcomes: a study with Brazilian companies
}

\author{
Robson Nogueira Tomas* and Rosane Lúcia Chicarelli Alcântara \\ Department of Industrial Engineering, University Federal of Sao Carlos, Sao Carlos, Brazil.
}

Accepted 16 August, 2013

\begin{abstract}
This paper explores practical linkages among external integration, supply chain risk reduction, and performance outcomes. Based on a survey questionnaire with 96 participants from industrial context of Brazil, we analyzed the total sample and we used the Wilcoxon-Mann-Whitney Test to comparing two sets of companies, that is, large companies (annual sales > US\$ 5 millions), and non-large companies (annual sales US\$ 1-5 millions). The findings indicate that companies with satisfactory levels of external integration have related lower supply chain risks. Our results also show that a higher level of external integration and risk reduction may lead to improved firm performance. Besides, we found that levels higher of external integration, risk reduction, and firm performance are perceived in large companies more than non-large companies. Finally, an important contribution of this paper lies in new avenues opened to research regarding benefits from supply chain integration on supply chain risks.
\end{abstract}

Key words: External integration, risk, performance, survey, Brazil, large companies.

\section{INTRODUCTION}

Over the last decades Supply Chain Management has been an essential element in the competitiveness of companies worldwide (Thun, 2010). Supply chain management aims to minimize costs while satisfying the requirements of service level (Rayeni and Saljooghi, 2012). However, the literature supports that supply chains are naturally affected by risks (Jüttner et al., 2003; Peck, 2006) threatening their performance (Ritchie and Brindley, 2007). Whereas the influence of supply chain integration on firm-performance has been studied widely (Frohlich and Westbrook, 2001; Green Jr. et al., 2008; Flynn et al., 2010; Swink et al., 2007; Zhao et al., 2011), the relationship between this theme and supply chain risk have not been exhaustively explored (Manuj and Mentzer, 2008).

From this perspective, is important to note that given the complexity and interdependence of various companies, in which the parameters of one organization may be affected by decisions made by other organizations, risks are rapidly evolving several companies (Masama et al., 2012) and it is an ever-present element in supply chains (Zsidisin, 2003; Peck, 2005; Wagner and Bode, 2006; Tang, 2006; Wagner and Bode, 2007; Rao and Goldsby, 2009). In this context it is observed that studies addressing the identification and mitigation of possible disturbances (Chopra and Sodhi, 2004; Finch, 2004), minimization of uncertainties (Jüttner et al., 2003; Peck, 2005) or interruptions (Wagner and Bode, 2006) has assumed a new degree of relevance in supply chain management (Peck, 2005).

Despite the increasing research interests in supply chain risk $(\mathrm{SCR})$ its relationship to other themes, or 
Table 1. Constructs, definition, and supporting literature.

\begin{tabular}{|c|c|c|}
\hline Construct & Definition & Supporting literature \\
\hline External Integration & $\begin{array}{l}\text { A set of practices focused on integration with its key supply } \\
\text { chain members (customers and suppliers) in order to fulfill } \\
\text { end customer requirements. }\end{array}$ & $\begin{array}{l}\text { Stank et al. (2001), Wong Lee et al. (2007), } \\
\text { Quesada et al. (2008), Zhao et al. (2011). }\end{array}$ \\
\hline Supply Chain Risk & $\begin{array}{l}\text { The potential occurrence of anything that may disrupt or } \\
\text { impede the information, material or product flows from } \\
\text { original suppliers to the ultimate user, affecting the } \\
\text { performance. }\end{array}$ & $\begin{array}{l}\text { Jüttner et al. (2003), Zsidisin (2003), Peck } \\
\text { (2006), Ritchie and Brindley (2007) }\end{array}$ \\
\hline $\begin{array}{l}\text { Market Share } \\
\text { Performance (MP) }\end{array}$ & $\begin{array}{l}\text { The organization's ability to increase sales and expand } \\
\text { market share as compared to its competition }\end{array}$ & Droge et al. (2004), Green Jr. et al. (2008) \\
\hline $\begin{array}{l}\text { Operational } \\
\text { Performance (OP) }\end{array}$ & The efficiency and effectiveness of internal areas of a firm. & $\begin{array}{l}\text { Stock et al.(2000), Zacharia et al. (2011), } \\
\text { Deravaj et al. (2007) }\end{array}$ \\
\hline $\begin{array}{l}\text { Financial } \\
\text { Performance (FP) }\end{array}$ & $\begin{array}{l}\text { The organization's profitability and return on investment as } \\
\text { compared to its competition. }\end{array}$ & $\begin{array}{l}\text { Droge et al. (2004), Green Jr. et al. (2008), } \\
\text { Lanier Jr. et al. (2010), Wagner et al. (2012) }\end{array}$ \\
\hline
\end{tabular}

explorations of linkages between SCR and other strategies, are still very limited (Manuj and Mentzer, 2008). Scholars have demonstrated the importance of researches on supply chain risk in Brazil (Rosales et al. 2012), a center and very important player in many global agribusiness supply chains. As discussed by Rosales et al. (2012) studies addressing risk reduction are widely adopted by companies in developed countries, and may also be of high importance to firms in developing countries. Increasingly, most studies on supply chain risk have been performed in the context of developed economies.

Thus, there are two main objectives for this research. First, we explore if levels high of supply chain risk reduction and performance outcomes are perceived in an industrial environment with satisfactory levels of external integration. Second, we determine if levels higher of external integration, supply chain risk reduction, and firm performance are perceived in largest companies more than non-large companies, in order to analyze similarities or differences in these two sets of companies.

The contributions to the literature include increased understanding of factors that influence the risk reduction and firm performance from external integration, as well as a comparison of two sets of companies, that is, large companies and non-large companies. This type of comparison is critical because the underlying assumption in supply chain management research is that the size of firms may influence levels of integration, whereas large firms tend to have more resources to integration activities in the supply chain. Therefore, this underlying assumption has not been readily tested (Zhao et al., 2011).

While previous studies have often examined supply chain risk, these studies have generally examined only customers' perspectives or only suppliers' perspectives; this research expands on such previous research by comparing both "sides" of the equation. Our research is to the best of our knowledge - the first paper analyzing this issue in the industrial context of Brazil.

In the following section, we briefly review the literature in external integration, supply chain risk, and firm performance to provide a theoretical foundation and rationale for our research. Next, the research metho-dology is described followed by research results. Finally, main conclusions are drawn, together with limitations of this study and suggestions for future research.

\section{THEORETICAL BACKGROUND}

In this paper, we have carefully defined each construct in terms of essential characteristics from the relevant literature base. The definition for each construct and the supporting literature is summarized in Table 1.

\section{External integration in the scope of this study}

External integration in the supply chain perspective involves the processes of collaboration with suppliers and customers to achieve mutually acceptable results (Pagell and Krause, 2004). Linkage with suppliers and with customers helps to reduce lead-time which undoubtedly reduce the adverse effects (e.g. bullwhip effects) and contribute to enhanced firm- performance (Won Lee et al., 2007).

Quesada et al. (2008) highlight the importance of 
supplier integration as a competitive competence, meriting management consideration and resources. Tan et al. (1998) suggest that when companies are integrated and act as a single entity, performance is shared throughout the chain. Similarly, collaborations and combined experience of both parties can help reduce errors, defects or flaws in routine, which leads to improved operational performance (Zacharia et al., 2011).

Customer integration refers to greater collaboration and information sharing activities with key customers, providing the firm with strategic insights into market expectations and business opportunities, and enabling a more efficient and effective response to the end customer (Shoenherr and Swink, 2012). Germain et al. (2008) argue that customer integration reduces unpredictable demand and leads to better financial performance.

\section{Effects of supplier and customer integration on supply chain risk reduction}

The issue of supply chain risk has received recent attention from scholars from around the world. According to Jüttner et al. (2003:127) "demand or supply risk sources arise from the interactions between the organizations within the supply chain, and there was a consensus that these risk sources become more important as the complexity of modern supply chains increases." Further, Wagner and Bode (2009) suggest that demand side and supply side risk sources represent the dominant and most prevalent supply chain risks.

Effective external integration with suppliers may enable organizations to reduce supply-side risks (Tang, 2006; Swink et al., 2007; Lin and Zhou, 2011). According to Lin and Zhou (2011) many companies are opting to develop strategic partnerships with their suppliers in order to minimize a certain amount of risk inherent in the supply. Tang (2006) indicates that the development of coordination mechanisms and integration offers increase in efficiency in the supply of materials along the chains. It is understood that integration efforts place external supply chain partners in a better position to understand and anticipate the needs of the next link, reducing uncertainties (Swink et al., 2007) and allowing the best capabilities to positively impact firm-performance (Shoenherr and Swink, 2012).

Effective external integration with customers may enable organizations to reduce demand-side risks, and to minimize potential occurrences of anything that may affect the focal firm ability to meet the requirements of customers and end-users (Wagner and Bode, 2007; Manuj and Mentzer, 2008). Through integration with customers, companies can better understand customer needs and respond more quickly to them. Integration with consumers contributes to demand planning, greater visibility in sharing information, and a consequent increase in the level of service (Boon-Itt and Wong, 2011).

\section{Effects of supply chain risk reduction on performance outcomes}

According to Hallikas and Varis (2009: 45) "the capacity to anticipate future development from the weak signals in the particular industry may result in better performance." More important, in the modern management decision context, it is accepted that risk and performance are directly and positively related (Ritchie and Brindley, 2007). Risk management enables identification and control of operational risks for maintenance or improvement of operational performance (Dani, 2009). Melnyk et al. (2009) highlight some risks which affect performance that can be grouped into three sets, namely, financial (e.g. inventory levels, costs, penalty clauses and others), market share (e. g. lost sales), and operational (lead time, quality, flexibility, fill rates).

Increasingly, performance in an industrial context lends itself to an almost infinite variety of definitions, many of which relate to specific issues or a single perspective (Ritchie and Brindley, 2007). However, in this study we adopt the perspective from Anthony (1965) which divides performance constructs into two elementary components, namely, efficiency and effectiveness. According to Campos-Garcia et al. (2012: 11819) "efficiency is the achievement of an objective, utilizing a minimum amount of resources." Thus, we consider market performance, operational performance, and financial performance as appropriate measures for the observation of efficiency and effectiveness in firm-performance. In line with Green Jr. et al. (2008) in this research we used sales and market share growth as the market performance measures. We used indicators such as perfect order, defect rates, rework rates and inventory levels as operational performance measures (Nyaga et al., 2010). Following Lanier Jr. et al. (2010) we used return on investment (ROI), net profit, and return on sales (ROS) as financial performance measures.

\section{Research gap}

There are evidences that supplier and customer integration positively impacts supply and demand risk and contributes to better business performance. Support for this interpretation can also be found in the broad literature on supply chain management which indicates supply chain integration practices can act as attenuators of supply and demand risk (Tang, 2006; Swink et al., 2007; Manuj and Mentzer, 2008; Lin and Zhou, 2011). However, several researchers highlight that this research field is not clearly verified in the literature, and those that 
Table 2. Characteristics of the respondents and companies.

\begin{tabular}{lclc}
\hline Characteristics & Respondents & Characteristics & Companies \\
\hline Job title & 9 & Industry type & \\
Director & 91 & Sugar and ethanol & 18 \\
Manager & 10 & Beef & 12 \\
Supervisor & 6 & Poultry and pork & 8 \\
Others & & Milk and dairy products & 8 \\
& & Fertilizers and pesticides & 13 \\
Job functions & 48 & Agricultural machines & 10 \\
SC Management & 2 & Oils and canned & 11 \\
Purchasing & 18 & Tobacco & 15 \\
Logistics & 6 & Number of employees & 1 \\
Distribution & 13 & $<100$ & 1 \\
Operations Management & 9 & $101-250$ & 8 \\
Others & & $251-500$ & 27 \\
& & $501-1,000$ & 36 \\
Years worked at organization & 19 & $>1,000$ & 24 \\
$<2$ & 60 & Annual sales & \\
2-5 years & 10 & US $\$ 1-5$ million & 70 \\
6-10 years & 7 & $>$ US $\$ 5$ million & 26 \\
$>10$ years & & & \\
\hline
\end{tabular}

are verified in many cases contain conflicting arguments. It is the interest of this paper to fill that existing gap.

\section{METHODOLOGY}

\section{Sample and data collection}

To examine two main objectives of this research, we conducted a nationwide survey with agribusiness industries in Brazil. Questionnaires were sent out to supply management professionals of the 50 largest companies (in sales for the year 2011) of the Brazilian agribusiness. The list of firms was derived the ranking Melhores e Maiores from Exame, year 2011 (www.exame.abril. com.br). This business periodical is an annual publication that presents the largest companies in Brazil, including agribusiness industries. For each of the 50 largest companies, we selected an average of 10 business units to receive the questionnaires. The total sample is 500 business units. We decided to direct the survey to directors or managers of the supply chain, purchasing, logistics or other leaders in the firm who have clarity and visibility of supply chains, logistics, purchasing and operations.

For data collection, we used a two-stage process. After a literature review and based on construct definitions, seven individuals (three professors in operations and supply chain management, two industry experts, and two Ph.D. candidates in operations management) were selected as participants in a pretest. The respondents were asked to provide feedback about question clarity and consistency with construct definitions. By incorporating their feedback, measurement items were modified, discarded or added to strengthen the constructs and content validity.

The data collection was realized between June and July 2012. For data collection we sent a letter in which the respondents were directed to respond to the survey in three ways: (1) by selecting the link that would take them to the online questionnaire, (2) by e-mail in PDF format or (3) by mail giving back a physical copy of questionnaire. The survey instrument consists of four parts. In the first part, we asked for information about the function of respondent and their company. In the second part, these respondents were asked about degree of integration internal and external of their company. Next, they indicated the levels of supply chain risk reduction. Finally, the participants described the degree of firm performance, compared with five years ago.

Of 500 surveys sent out, 98 surveys were returned 96 were complete and useable responses. The response rate was 19.2 percent (96/500). This response rate compares closely to that reported in recent supply management papers. We attempted to minimize nonresponse bias through the use of introductory letters and assurance of confidentiality. All respondents were offered a report of main results as an incentive to complete and return the questionnaire. We tested for nonresponse bias by first comparing company demographics of the responding firms to those of the nonresponding companies. Then, we compared responses for the early and late respondents (Armstrong and Overton, 1977). The tests suggest that nonresponse bias is not present. Table 2 summarizes characteristics of respondents and companies.

\section{Measurement item development}

We adapted existing scales to measure our constructs. Supply chain integration was assessed using items adapted from (Droge et al., 2004; Devaraj et al., 2007; Flynn et al., 2010; Shoenherr and Swink, 2012). Risk reduction was measured using a new scale developed for this study. While no existing measurement was available, the steps suggested by Grawe et al. (2009) provided the basis for this item generation. The measurement items of risk reduction were operationalized by five sets of attributes: (1) reprogramming of production or disruptions of planning (Tang and Tomlin, 2009); (2) demand fluctuations due to sales promotions, order batching, and price (Wagner and Bode, 2009); (3) insufficient 
or distorted information from customers about orders and disruptions in the physical distribution of products (Wagner and Bode, 2009); (4) capacity constraints and threat of financial instability of suppliers (Zsidisin, 2003), and (5) supplier quality problems and poor information sharing (Wagner and Bode, 2009). Market, operational, and financial performance was measured using items adapted from (Droge et al., 2004; Devaraj et al., 2007; Nyaga et al., 2010; Lanier Jr. et al., 2010).

\section{Measurement model}

First of all, the constructs were submitted to the Cronbach's Alpha coefficient (using the AMOS 18.0) to check whether these constructs are consistent (that is construct validity) aiming fulfill conditions of analysis. The Cronbach's Alpha should be the first measure to be calculated to assess the quality of the instrument as it is the basic statistics to determine the reliability of a measure based on internal consistency (Churchil, 1999). With conditions of Cronbach's Alpha satisfied, we calculate means and standard deviations of each issue.

The Wilcoxon-Mann-Whitney Test is a nonparametric test that compares two independent groups. This test has two important assumptions. First the two samples under consideration are random, and are independent of each other, as are the observations within each sample. Second the observations are numeric or ordinal, that is, arranged in ranks (Marôco, 2011). Table 3 shows measurement items and descriptive statistics.

Comparing two independent samples, the Wilcoxon MannWhitney test does not assume that the difference between the samples is normally distributed whereas its parametric counterpart, the two sample t-test does (Fay and Proschan, 2010).

\section{DISCUSSION AND IMPLICATIONS}

As mentioned earlier, the literature supports that supply chains are naturally affected by risks, which threaten their performance. In this sense, studies addressing the identification and mitigation of possible disturbances, minimization of uncertainties or interruptions have assumed a new degree of relevance in supply chain management context. From this scenario, our study revealed the importance of external integration practices to mitigate supply chain risk and lead to improved performance outcomes (Figure 1).

In the past decade (2001 to 2010), the Brazilian agribusiness accounted for $25 \%$ of Gross Domestic Product (GDP) of Brazil. Actually, Brazilian agribusiness is currently employing approximately $38 \%$ of the labor force in Brazil. In 2010, the GDP of the sector reached US\$ 421.1 billion, which represented $22.3 \%$ of Brazilian GDP. From an economic standpoint, this sector is distinguished from the others due to the high number of companies formally established, the production capacity, the potential to generate trade surpluses from exports and generation of new jobs. The Brazilian agribusiness industries are considered - along with the automotive industry - the starting point of external integration practices in Brazil. Besides, the Brazilian agribusiness industries are also facing other challenges, such as company mergers, changes in consumers' preferences and requirements for increased efficiency and low prices, which create pressures for the supply chain as a whole. We may thus conclude that risk reduction should be a highly prioritized managerial issue to Brazilian agribusiness industries. The results as shown in Tables 4 and 5 which indicate that the purpose of this research was supported broadly.

In this study all constructs (Table 4) showed good internal consistency with Cronbach's coefficient (above 0.70 , as suggested by Hair Jr. et al. (2010)). The findings indicate that companies with satisfactory levels of external integration have related lower supply chain risk. Our results are supported by the literature showing that suppliers and customers integration has a beneficial effect on risk reduction. Our results also indicate that a higher level of external integration and risk reduction may lead to improved performance outcomes. Both relationships are found to be statistically significant $(p<0.01$ showed in Table 5), which supports the idea that external integration and risk reduction contribute to better performance outcomes.

This is an important finding, it adds to the literature by empirically testing the relationship between external integration and supply chain risk reduction. In including both supplier and customer integration and their interactions with risks, and incorporating market, financial and operational performance, this study adds greater comprehensiveness and richness to the supply chain risk literature, and enhances our understanding of the impact of external integration on both supply chain risk reduction and firm performance.

In today's competitive environment companies need to cooperate closely with their suppliers and customers to meet various challenges, and respond to an environment full of uncertainties (Zhao et al., 2011). In this regard, our research provides significant implications for agribusiness industries in Brazil, as well as for different industries, by indirectly linking external integration to business performance through risk reduction.

According to the response profile in Table 5, we found that levels higher of external integration, risk reduction, and firm performance are perceived in largest companies more than non-large companies. Our findings show that non-large companies not are engaged in external integration such which large companies. In this sense, the samples of the tests showed a $p$ value lower than 0.001 which means that the results could be viewed as highly significant (Hu and Bentler, 1999). In terms of risk reduction our findings allow to state that levels higher also are perceived in large companies more than nonlarge industries (10.9 and 4.2 respectively).

Another very interesting finding is the level higher of market, financial and operational performances are perceived in large companies more than non-large industries. The results of the tests were significant for the path with a performance variation that favored the large 
Table 3. Measurement items and descriptive statistics.

\begin{tabular}{|c|c|c|c|c|}
\hline \multirow{3}{*}{$\begin{array}{l}\text { Variables and scale scores } \\
\text { Supplier and customer integration }^{\text {b }} \\
\text { Adapted from Droge et al. (2004) Devaraj et al. (2010) Flynn et al. (2010) } \\
\text { SI - Supplier Integration }\end{array}$} & \multicolumn{2}{|c|}{ Large } & \multicolumn{2}{|c|}{ Non-Large } \\
\hline & \multirow[b]{2}{*}{ (Mean) } & \multirow[b]{2}{*}{$\left(S D^{a}\right)$} & \multirow[b]{2}{*}{ (Mean) } & \multirow[b]{2}{*}{$\left(S D^{a}\right)$} \\
\hline & & & & \\
\hline 1 My company provides suppliers with information forecasting demand & 6.338 & 0.511 & 5.220 & 1.219 \\
\hline 2 My company shares important information with our suppliers & 6.604 & 0.719 & 5.208 & 1.119 \\
\hline 3 My company shares its production plans with suppliers & 6.315 & 0.770 & 5.185 & 1.154 \\
\hline 4 My company has integrated management of demand forecast & 6.591 & 0.358 & 5.429 & 1.244 \\
\hline 5 My company shares important information with our suppliers & 6.105 & 1.005 & & 1.233 \\
\hline 6 Our suppliers participate in the design phase of our products & 4.888 & 2.006 & 3.050 & 2.214 \\
\hline 7 There is connection between the computers of our company and our & 5.669 & 0.563 & 3.851 & 2.767 \\
\hline 8 Our company knows of production capacity of our suppliers & 6.852 & 0.651 & 5.106 & 1.183 \\
\hline 9 Our company shares the cost inforn & 5.812 & 0.826 & 4.958 & 1.626 \\
\hline 10 Our company share information on production in real-time with suppliers & 5.690 & 1.116 & 4.852 & 1.660 \\
\hline \multicolumn{5}{|l|}{$\mathrm{Cl}$ - Customer Integration } \\
\hline 11 Our clients provide their forecast demand for our company & 6.850 & 0.536 & 3.400 & 1.006 \\
\hline 12 Our clients can easily monitor the status of their orders placed & 6.781 & 0.663 & 4.189 & 1.447 \\
\hline 13 Our customers jointly coordinate with my company the planning of produ & 6.472 & 0.562 & 3.498 & 1.316 \\
\hline 14 My company shares resources with the clients, such as deposits and facilities & 6.224 & 0.665 & 3.652 & 1.635 \\
\hline 15 Our clients and my company do jointly development of new products & 6.589 & 1.002 & 2.099 & 2.514 \\
\hline 16 Our customers and my company jointly identify opportunities for new markets & 6.351 & 0.554 & 2.545 & 1.526 \\
\hline 17 Our company carries out integrated management of demand with our & 6.895 & 0.365 & 4.981 & 1.419 \\
\hline 18 Our company carries & 6.889 & 0.410 & 3.569 & 1.390 \\
\hline 19 Our customers have access in real time abol & 6.703 & 1.005 & 4.213 & 1.241 \\
\hline \multicolumn{5}{|l|}{ *SCRR - Supply Chain Risk Reduction ${ }^{\text {b }}$} \\
\hline 20 In my company the variations in demanc & 5.747 & 0.546 & 4.127 & 2.140 \\
\hline 21 The main $s$ & 6.591 & 1.057 & 5.117 & 1.317 \\
\hline d operational performance of suppliers & 5.933 & 0.349 & 3.671 & 2.337 \\
\hline 23 My company obtain flexibility of its suppliers when occur emergency requests & 6.898 & 0.541 & 4.332 & 1.599 \\
\hline 24 Distribution operations are casually affected by events of variability in demand & 5.980 & 0.978 & 3.020 & 2.094 \\
\hline 25 Key suppliers are able to meet a minimum of $90 \%$ of deliveries on-time & 6.586 & 0.472 & 5.856 & 1.330 \\
\hline 26 Our company has the flexibility to solve problems of supply deliveries out time & 6.516 & 0.956 & 5.068 & 1.214 \\
\hline \multicolumn{5}{|l|}{${ }^{\star \star}$ MP - Market Performance ${ }^{c}$} \\
\hline 27 Sales volume & 4. & 0.668 & 3.238 & 1.290 \\
\hline 28 Market share & 4.055 & 0.541 & 3.257 & 1.423 \\
\hline \multicolumn{5}{|l|}{${ }^{\star \star} F P$ - Financial Performance ${ }^{c}$} \\
\hline 29 Return on investment (ROI) & 4.212 & 0.862 & & 1.052 \\
\hline 30 Net Profit & 4.015 & 0.652 & 2.797 & 1.220 \\
\hline 31 Return on sales (ROS) & 4.223 & 0.785 & 2.589 & 1.041 \\
\hline \multicolumn{5}{|l|}{${ }^{\star *}$ OP - Operational Performance ${ }^{c}$} \\
\hline 32 Lead time production & 4.011 & 0.770 & 2.781 & 1.166 \\
\hline 33 Perfect order & 4.703 & 0.874 & 2.131 & 1.088 \\
\hline 34 Inventory levels (raw material, materials in process and finished & 4.211 & 0.592 & 2.597 & 1.396 \\
\hline 35 Defect and rework rates & 4.231 & 1.025 & 3.685 & 1.267 \\
\hline
\end{tabular}

Notes: ${ }^{a}$ Standard Deviation; ${ }^{\mathrm{b}}$ Items were measured using a seven-point Likert-type scale, where $1=$ strongly disagree and $7=$ strongly agree. ${ }^{c}$ items were measure using a five-point scale, where $1=$ worse, $2=$ stayed about the same, $3=$ improved 10 to $30 \%, 4=\mathrm{improved}$ 30 to $50 \%, 5$ = improved more than 50\%, if compared with five years ago.* Developed from Zsidisin (2003) Tang and Tomlin (2009) Wagner and Bode (2009). ${ }^{* \star A d a p t e d ~ f r o m ~ D r o g e ~ e t ~ a l . ~(2004), ~ N y a g a ~ J r . ~ e t ~ a l . ~(2010), ~ L a n i e r ~ J r . ~ e t ~ a l . ~(2010), ~ D e v a r a j ~ e t ~ a l . ~(2010) . ~}$ 
Table 4. Total sample results.

\begin{tabular}{llcccc}
\hline Issues & Variable & Sample & Mean of scores & Mean *SD ranks & ${ }^{* \star}$ Cronbach's Alpha \\
\hline $1-10$ & Supplier Integration & 96 & 5.441 & 1.197 & 0.850 \\
$11-19$ & Customer Integration & 96 & 5.105 & 1.070 & 0.828 \\
$20-26$ & SC Risk Reduction & 96 & 5.389 & 1.209 & 0.835 \\
$27-28$ & Market Performance & 96 & 3.667 & 0.981 & 0.962 \\
$29-31$ & Financial Performance & 96 & 3.402 & 0.935 & 0.961 \\
$32-35$ & Operational Performance & 96 & 3.544 & 1.022 & 0.952 \\
\hline
\end{tabular}

Notes: * Standard Deviation ${ }^{* *}$ Cronbach's Alpha: acceptable coefficient > 0.7 (Hair Jr. et al., 2010).

Table 5. Path results from large and non-large companies.

\begin{tabular}{|c|c|c|c|c|c|c|c|}
\hline Issues & Variable & Companies & Mean rank & Sum rank & $\chi^{2} /$ d.f ${ }^{a}$ & $p$-value & Relationship \\
\hline \multirow{2}{*}{$1-10$} & \multirow{2}{*}{ Supplier Integration } & Large (L) & 14.80 & 148.0 & \multirow{2}{*}{1.503} & \multirow{2}{*}{$* * *$} & \multirow{2}{*}{$\mathrm{L}>\mathrm{NL}$} \\
\hline & & Non-large (NL) & 6.20 & 62.0 & & & \\
\hline \multirow{2}{*}{$11-19$} & \multirow{2}{*}{ Customer Integration } & Large (L) & 14.0 & 126.0 & \multirow{2}{*}{1.279} & \multirow{2}{*}{$* * *$} & \multirow{2}{*}{$\mathrm{L}>\mathrm{NL}$} \\
\hline & & Non-large (NL) & 5.0 & 45.0 & & & \\
\hline \multirow{2}{*}{$20-26$} & \multirow{2}{*}{ SC Risk Reduction } & Large (L) & 10.9 & 76.0 & \multirow{2}{*}{0.916} & \multirow{2}{*}{ ** } & \multirow{2}{*}{$L>N L$} \\
\hline & & Non-large (NL) & 4.2 & 29.0 & & & \\
\hline \multirow[t]{2}{*}{$27-28$} & \multirow{2}{*}{ Market Performance } & Large $(\mathrm{L})$ & 3.5 & 7.0 & \multirow{2}{*}{0.240} & \multirow{2}{*}{ ** } & \multirow{2}{*}{$\mathrm{L}>\mathrm{NL}$} \\
\hline & & Non-large (NL) & 1.5 & 3.0 & & & \\
\hline \multirow[t]{2}{*}{$27-28$} & \multirow{2}{*}{ Financial Performance } & Large (L) & 5.0 & 15.0 & \multirow{2}{*}{0.386} & \multirow{2}{*}{ ** } & \multirow{2}{*}{$\mathrm{L}>\mathrm{NL}$} \\
\hline & & Non-large (NL) & 2.0 & 6.0 & & & \\
\hline \multirow{2}{*}{$27-28$} & \multirow{2}{*}{ Operational Performance } & Large (L) & 6.5 & 26.0 & \multirow{2}{*}{0.533} & \multirow{2}{*}{ ** } & \multirow{2}{*}{$\mathrm{L}>\mathrm{NL}$} \\
\hline & & Non-large (NL) & 2.5 & 10.0 & & & \\
\hline
\end{tabular}

Notes: ${ }^{* *}<0.01 ;{ }^{* * *}<0.001 .{ }^{a}$ Acceptable values: equal or less than 5.0 (Hair Jr. et al., 2010).

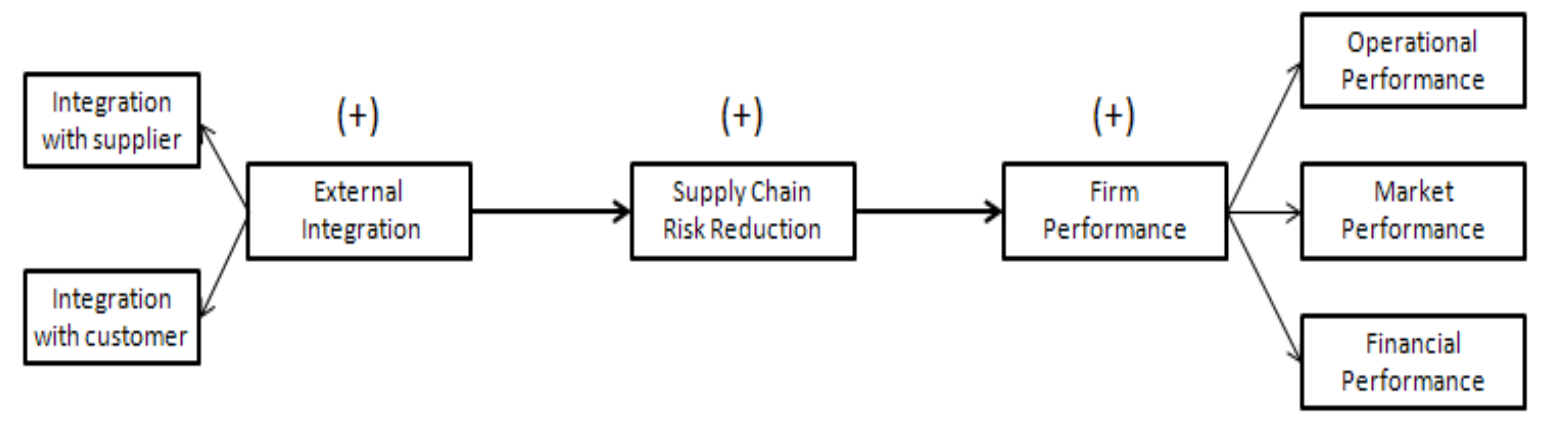

Figure 1. Framework illustrating the main results of this study.

companies group ( $p$ value $<0.01$ ) (Hu and Bentler, 1999). To the best of our knowledge, this is pioneering information. Previous research has related that risk reduction and performance are directly and positively related (Ritchie and Brindley, 2007).

However, in terms of what performance types are 
benefited by risk reduction, none have addressed this link in the Brazilian industrial context. Future longitudinal studies could be conducted to better investigate this issue. Therefore, our research reinforces the importance of external integration in widely improving supply chain risks. This is an important finding, since much of the extant literature on relationship the between external integration and risk reduction does not include widely this perspective.

\section{Conclusions and limitations}

Using a nationwide survey with Brazilians agri-industrial companies, we show that: a) supply chain risk reduction and better performance outcomes are perceived in companies with satisfactory levels of external integration, and; b) levels higher of external integration, supply chain risk reduction, and firm-level performance are perceived in largest companies more than non-large companies. Other important contribution of this research lies with the embedding of these concepts in analyze from the perspective of a developing economy. Seen in this light it is noteworthy that such findings may contribute to the understanding of risk reduction outcomes in companies from other developing countries.

While this study extends the supply chain risk literature, there are also some limitations along with more opportunities for future research. First, our findings are based on single respondent data. Even though the respondents were prequalified and had direct experience with supply chain management, the same individual provided information on all measures of constructs, which could potentially bias the results. Second, because the data were only collected from agribusiness industries, future studies can broaden their scope by collecting data from several supply chains, including suppliers, manufacturers, and customers. Third, although this research provided some interesting findings about this complex relationship in Brazil, it is not clear whether these relationships will be the same in other countries. Future research should examine differences in this relationship in others countries, in particular, in developed versus developing economies.

\section{ACKNOWLEDGMENTS}

The authors would like to acknowledge the financial support provided by the Sao Paulo Research Foundation - FAPESP.

\section{REFERENCES}

Anthony RN (1965). Planning and Control Systems: A Framework for Analysis. Harvard U. S. B. A., Boston, MA.
Armstrong JS, Overton TS (1977). Estimating nonresponse bias in mail surveys. J. M. Res. 14(3):396-402.

Boon-Itt S, Wong CY (2011). The moderating effects of technological and demand uncertainties on the relationship between supply chain integration and customer delivery performance. Int. J. Phy. Dist. \& Log. Manage. 41(3):253-276.

Campos-Garcia RM, Garcia-Vidales MA, Garcia-Vidales MY, GonzalesGomez O, Altamirano-Corro A (2012). Logistics efficiency in small and medium enterprises: A logistics, data envelopment analysis combined with artificial neural network (DEA-ANN) approach. Afr. J. Bus. Manage. 6(49):11819-11827.

Chopra S, Sodhi MS (2004). Managing risk to avoid supply chain breakdown. MIT Sloan Manage. Rev. 46(1):53-61.

Churchil Jr. GA (1999). Marketing research: methodological foundations, 7 ed. Inter. Thomson Publishing, New York, NY.

Dani S (2009). Predicting and managing supply chain risks, in Zsidisin GA, Ritchie B (Eds.) Supply chain risk, Springer, New York, NY, USA pp.53-64.

Devaraj S, Krajewski L, Wei JC (2007). Impact of e-business technologies on operational performance: the role of production information integration in the supply chain. J. Operat. Manage. 25:1119-1216.

Droge C, Jayaram J, Vickery SK (2004). The effects of internal versus external integration practices on time-based performance and overall firm performance. J. Operat. Manage. 22(6):557-573.

Fay MP, Proschan MA (2010). Wilcoxon-Mann-Whitney or t-test? On assumptions for hypothesis test and multiples interpretations of decision rules. Stat. Surv. 4:1-39.

Finch $P$ (2004). Supply chain risk management. Supply chain manage.: Int. J. 9(2):183-96.

Flynn BB, Huo B, Zhao X (2010). The Impact of supply chain integration on performance: a contingency and configuration approach. J. Oper. Manage. 28(1):58-71.

Frohlich MT, Westbrook R (2001). Arcs of integration: an international study of supply chain strategies. J. Oper. Manage. 19(2):185-200.

Germain R, Claycomb C, Droge C (2008). Supply chain variability organizational structure and performance the moderating effect of demand unpredictability. J. Oper. Manage. 26(5):557-570.

Grawe SJ, Chen H, Daugherty PJ (2009). The relationship between strategic orientation, service innovation and performance. Int. J. Phys. Dist. Log. Manage. 39(4):282-300.

Green Jr. KW, Whitten DR, Inman RA (2008). The impact of logistics performance on organizational performance in a supply chain context. Supply chain manage.: Int. J. 13(4):317-327.

Hair J, Black W, Babin B, Anderson R (2010). Multivariate data analysis, 7th ed., Prentice-Hall, Inc. Upper Saddle River, NJ, USA

Hallikas J, Varis J (2009). Risk management in supply chains, in Zsidisin GA, Ritchie B (Eds.) Supply chain risk, Springer, New York, NY, USA pp.35-52.

Hu L, Bentler PM (1999). Cutoff criteria for fit indexes in covariance structure analysis: conventional criteria versus new alternatives. Struc. Equat. Model. 6(1):1-55.

Jüttner U, Christopher M, Peck H (2003). Supply chain risk management outlining an agenda for future research. Int. J. Logist. Manage. 6(4):197-210.

Lanier Jr. D, Wempe WF, Zacharia ZG (2010). Concentrated supply chain membership and financial performance: chain - and firm-level perspectives. J. Oper. Manage. 28:1-16.

Lin Y, Zhou L (2011). The impacts of product design changes on supply chain risk: a case study. Int. J. Phys. Dist. Log. Manage. 41(2):162186.

Manuj I, Mentzer JT (2008). Global supply chain risk management strategies. Int. J. Phys. Dist. Log. Manage. 38(3):192-223.

Marôco J (2011). Análise Estatística com o SPSS Statistics. Report Number, Pero Pinheiro, Portugal (in Portuguese).

Masama BT, Ndlovu E, Mambwe T, Rabahome C, Chakabva O, Fologang B, Badze T, Bruwer JP (2012). Enterprise risk management: a managing 'partner' for business success. Afr. J. Bus. Manage. 6(48):11782-11786.

Melnyk SA, Rodrigues A, Ragatz GL (2009). Using simulation to 
investigate supply chain disruptions, in Zsidisin GA, Ritchie B (Eds.), Supply chain risk, Springer, New York, NY, USA pp.103-120.

Nyaga GN, Whipple JM, Lynch DF (2010). Examining supply chain relationship: do buyer and supplier perspectives on collaborative relationship differ. J. Oper. Manage. 28:101-114.

Pagell M, Krause D (2004). Re-exploring the Relationship between Flexibility and the External Environment. J. Oper. Manage. 21(6):629649.

Peck H (2005). Drivers of supply chain vulnerability: an integrated framework. Int. J. Phys. Dist. Log. Manage. 36(4):210-232.

Peck H (2006). Reconciling supply chain vulnerability risk and supply chain management. Int. J. Logist.: Res. Appl. 9(2):124-142.

Quesada G, Rachamadugu R, Gonzales M, Martinez JL (2008). Linking order winning and external supply chain integration strategies. Supply chain manage.: Int. J. 13(4):296-303.

Rayeni MM, Saljooghi FH (2012). Evaluating performance of supply chain based on network data envelopment analysis. Afr. J. Bus. Manage. 6(47):11575-11582.

Rao S, Goldsby T (2009). Supply chain risks: a review and typology. Int. J. Logist. Manage. 20(1):97-123.

Ritchie B, Brindley C (2007). Supply chain risk management and performance: a guiding framework for future development. Int. J. Oper. Prod. Manage. 27(3):303-322.

Rosales FP, Tomas RN, Pimenta ML, Batalha MO, Alcantara RLC (2012). Risk and agri-food supply chain performance: perceptions from initial analysis. Paper presented at the 19th Int. An. EUROMA Conference, Amsterdam, Netherlands.

Shoenherr T, Swink M (2012). Revisiting the arcs of integration: crossvalidations and extensions. J. Oper. Manage. 30(1-2):99-115.

Stank TP, Keller SB, Daugherty PJ (2001). Performance benefits of supply chain logistical integration. Transport. J. 41(2/3):32-46.

Stock GN, Greis NP, Kasarda JD (2000). Enterprise logistics and supply chain structure: the role of fit. J. Oper. Manage. 18(5):531-547.

Swink M, Narasimhan R, Wang C (2007). Managing beyond the factory walls: effects of four types of strategic integration on manufacturing plant performance. J. Oper. Manage. 25(1):148-164.

Tan KC, Kannan VR, Handfield RB (1998). Supply chain management: supplier performance and firm performance. Int. J. Purch. Mater. Manage. 34(3):2-9.
Tang CS (2006). Perspectives in supply chain risk management. Int. J. Prod. Econ. 103(2):451-488.

Tang C, Tomlin B (2009). How much flexibility does it take to mitigate supply chain risk? in Zsidisin GA, Ritchie B (Eds.) Supply chain risk, Springer, New York, NY, USA pp.155-174.

Thun JH (2010). Angles of integration: an empirical analysis of the alignment of internet-based information technology global supply chain integration. J. Supply Chain Manage. 46(2):30-44.

Wagner SM, Bode C (2006). An empirical investigation into supply chain vulnerability. J. Purch. and Sup. Manage. 12(6):301-312.

Wagner SM, Bode C (2007). An empirical examination of supply chain performance along several dimensions of risk. J. Bus. Logist. 29(1):307-325.

Wagner SM, Bode C (2009). Dominant risks and risk management practices in supply chain, in Zsidisin GA, Ritchie B (Eds.) Supply chain risk, Springer, New York, NY, USA pp.271-287.

Wagner SM, Grosse-Ruyken PT Erhun F (2012). The link between supply chain fit and financial performance of the firm. J. Oper. Manage. 30:340-353.

Won Lee C, Ik-whan GK, Severance DM (2007). Relationship between supply chain performance and degree of linkage among supplier internal integration and customer. Supply chain manage.: Int. J. 12(6):444-452.

Zacharia ZG, Nix NW, Lusch RF (2011). Capabilities that enhance outcomes of an episodic supply chain collaboration. J. Oper. Manage. 29(1-2):591-603.

Zhao X, Huo B, Selen W, Yeung J (2011). The impact of internal integration and relationship commitment on external integration. J. Oper. Manage. 29(1-2):17-32.

Zsidisin GA (2003). Managerial perceptions of supply risk. J. Supply Chain Manage. 39(1):14-25. 